\title{
Restoring plant species diversity and community composition in a ponderosa pine-bunchgrass ecosystem
}

\author{
Daniel C. Laughlin · Jonathan D. Bakker • Mark L. Daniels • \\ Margaret M. Moore $\cdot$ Cheryl A. Casey $\cdot$ Judith D. Springer
}

Received: 12 January 2007/ Accepted: 4 October 2007/Published online: 18 October 2007

(C) Springer Science+Business Media B.V. 2007

\begin{abstract}
Monitoring of ecological restoration treatments often focuses on changes in community structure and function. We suggest that long-term changes in community composition also need to be explicitly considered when evaluating the success of restoration treatments. In 1992, we initiated an experiment in a ponderosa pine-bunchgrass ecosystem to evaluate responses to restoration treatments: (a) thinning the overstory vegetation ('thinning'), (b) thinning plus forest floor manipulation with periodic prescribed burning ('composite'), and (c) untreated 'control.' Treatments were further stratified by forest patch type: presettlement tree clumps (trees that established prior to the onset of fire exclusion in 1876), patches of retained postsettlement trees, patches where all postsettlement trees were
\end{abstract}

D. C. Laughlin $(\bowtie) \cdot$ M. L. Daniels · J. D. Springer Ecological Restoration Institute, Northern Arizona University, P.O. Box 15017, Flagstaff, AZ 86011, USA e-mail: daniel.laughlin@nau.edu

D. C. Laughlin · M. M. Moore

School of Forestry, Northern Arizona University, P.O. Box 15018, Flagstaff, AZ 86011, USA

J. D. Bakker

College of Forest Resources, University of Washington, P.O. Box 354115, Seattle, WA 98195, USA

C. A. Casey

Yavapai College, 1100 East Sheldon St., Prescott, AZ 86301, USA removed, and remnant grass openings. Species richness did not differ among treatments for 10 years, but was highest in the composite treatment in 11 th and 12th year after initial treatment. Community composition diverged among treatments 5 years after initial treatment, and compositional changes were greatest in the composite treatment. Species richness and composition differed among patch types prior to treatment. Remnant grass patches were the most diverse and presettlement patches were the least diverse. Following treatment, species richness in the postsettlement removed and retained patches, gradually approached levels found in remnant grass patches. Compositional differences among patch types changed a little by 2005 . Species richness at the $2 \mathrm{~m}^{2}$ scale increased only where the overstory was thinned and the understory was burned. However, these changes may not be detectable for many years, and can vary temporally in response to events such as severe droughts. Nonnative species establishment may be reduced by scheduling longer burn intervals or by refraining from burning where fuel loads are not hazardous, though these options may hinder goals of increasing diversity. Restoring species diversity and community composition continues to be more difficult than restoring ecosystem structure and function.

Key-words Long-term studies - Permutational MANOVA · Pinus ponderosa - Prescribed fire . Species richness $\cdot$ Thinning $\cdot$ Understory 


\section{Introduction}

Evaluations of management or ecological restoration treatments should consider changes in community structure, function, and composition, but these community attributes are not given equal weight in most assessments. Structural components such as tree density are the simplest to measure and interpret (e.g., Covington et al. 1997). Functional attributes such as net primary productivity are more difficult to measure, and therefore, correlated variables, such as peak herbaceous standing crop, are used instead (e.g., Tilman et al. 2002; Moore et al. 2006). Compositional metrics can be difficult to interpret given their multidimensional nature (Legendre and Legendre 1998; McCune and Grace 2002) and are rarely considered in the context of ecological restoration, in part because long-term data are necessary to detect compositional trends (Lindborg and Eriksson 2004). However, we suggest that composition should be explicitly considered because having restored ecosystem structure and functioning does not necessarily mean that composition has also been restored (Lockwood and Pimm 1999), and often there is not a direct relationship between species diversity, composition, and ecosystem functioning (Schwartz et al. 2000; Cortina et al. 2006). For example, an area with the desired plant cover and standing crop could be dominated by nonnative species, and therefore, be a failure with respect to plant community composition (e.g., Christian and Wilson 1999). Given that a community's composition is the net effect of births, deaths, immigrations, and emigrations of individuals of many species, composition is likely to respond more slowly than many structural and functional attributes. However, we often do not know the temporal or spatial scales, at which species richness and composition change given the differences in lifespan and dispersal capabilities among species.

Montane ponderosa pine forests in the southwestern United States have been fundamentally altered during the past century through the synergistic effects of livestock overgrazing, fire exclusion, overstory harvesting, and climatic events (Allen et al. 2002). Together, these have resulted in dramatic increase in the density of ponderosa pine (Pinus ponderosa P. \& C. Lawson var. scopulorum Engelm.), which in turn have led to reduced diversity and altered assemblages of herbaceous plants (Covington and Moore 1994;
Bakker and Moore 2007). Diversity theories predict that species richness will increase when a dominant species is removed from a community (Grime 1979; Tilman 1982; Keddy 2005). Thus, thinning dense stands of ponderosa pine should allow for the colonization and establishment of herbaceous understory species, leading to greater diversity in the understory. However, removing a dominant plant does not always lead to increased diversity (e.g., MacDougall and Turkington 2005; Keddy et al. 2006).

In 1992, a long-term restoration project was implemented in a ponderosa pine-bunchgrass ecosystem in northern Arizona. The project involved thinning the ponderosa pine overstory, and conducting repeated prescribed burns. The original goals of this project were to restore the pre-Euroamerican settlement forest structure (tree density, age and spatial structure; Mast et al. 1999) and to increase herbaceous understory standing crop. These original goals were successfully met (Covington et al. 1997; Moore et al. 2006), though restoration success was highly dependent on local microenvironment; that is, herbaceous standing crop beneath patches of trees was generally unresponsive to treatments, even though areas were burned periodically (Laughlin et al. 2006).

In this article, we evaluated herbaceous understory species richness and community composition in areas subject to no treatment ('control'), a one-time selective tree thinning in 1993 ('thinning'), and selective tree thinning followed by prescribed fires every 4 years ('composite'). We predicted that species richness would increase and community composition would diverge within treated areas relative to control areas. We also examined whether differences in richness and composition among patch types (i.e., forest patches ranging from full canopy to no canopy) persist following restoration, and whether response to restoration treatment differs among patch types. Remnant grass patches are productive and species rich, and provide the best example of reference conditions with respect to the understory vegetation in this system (Laughlin et al. 2006). We, therefore, used these patches as the reference to assess restoration success. We predicted that herbaceous vegetation in patches where small-diameter trees were removed, would become more similar to the remnant grass patches. The long-term duration of 
this project (1992-2005) permitted us to evaluate the temporal dynamics of richness and composition. Finally, we tested whether individual plant species could be identified as indicators of restoration treatments or patch types.

\section{Methods}

Study system

This study was conducted at the Gus Pearson Natural Area (GPNA), located $\sim 10 \mathrm{~km}$ northwest of Flagstaff, Arizona in the Fort Valley Experimental Forest in the Coconino National Forest. The $\sim 4.3$ ha study site ranges from 2,195 to $2,255 \mathrm{~m}$ in elevation, and has a flat to gently rolling topography. Soils are derived from Tertiary basalt flows and cinders, and are classified as a Brolliar stony clay loam and a complex of fine, smectitic Typic Argiborolls and Mollic Eutroboralfs (Kerns et al. 2003). The average annual temperature is $7.5^{\circ} \mathrm{C}$. Average annual precipitation is $\sim 570 \mathrm{~mm}$, and follows a bimodal pattern with approximately half of the precipitation occurring as rain in July and August, and half as snow in the winter (NOAA 2005). Drought was common during this study. A severe drought occurred in 2002, when precipitation was $77 \%$ below normal at the study area (Moore et al. 2006).

The study area has been ungrazed by livestock for more than 50 years (Olberding 2000). A few trees were removed from GPNA in 1894, but it did not receive commercial harvest after that time (Avery et al. 1976). Although timber harvest was minimal, tree density in 1992 (prior to treatment) was $>3,000$ trees $\mathrm{ha}^{-1}$ (Covington et al. 1997). These high densities existed due to favorable climatic events for regeneration and the exclusion of fire from the study area since 1876 (Dietrich 1980).

Ponderosa pine is the only tree species on the study site. The understory is dominated by native perennial graminoid species, including Festuca arizonica Vasey (Arizona fescue), Elymus elymoides (Raf.) Swezey ssp. elymoides (bottlebrush squirreltail), Muhlenbergia montana (Nutt.) A. S. Hitchc. (mountain muhly), Poa fendleriana (Steud.) Vasey (muttongrass), and Carex geophila Mackenzie (White Mountain sedge). Dominant native perennial forb species include Vicia spp. (combination of
$V$. americana Muhl. Ex. Willd. and $V$. pulchella Kunth), Astragalus rusbyi Greene (Rusby's milkvetch), Lupinus argenteus Pursh (silvery lupine), Achillea millefolium L. var. occidentalis DC. (western yarrow), and Cirsium wheeleri (Gray) Petrak (Wheeler's thistle). Six exotic species were recorded at the site during this study, with the two most common being the biennial forb Verbascum thapsus L. (common mullein) and the perennial graminoid Poa pratensis L. (Kentucky bluegrass).

\section{Experimental design}

Fifteen treatment plots, each $0.2-0.3$ ha, were established in 1992. Each treatment plot was assigned to one of the three treatments (control, thinning, or composite) to yield five replicates per treatment. The five control plots were located nonrandomly on one side of the study site, while the thinning and composite treatment plots were assigned randomly. This design was necessary so that the fuel break created by the treated plots would protect the historical buildings of the adjacent Fort Valley Experimental Station. The control plots are located at the same elevation, and have similar slopes, aspects, and soil types as the treatment plots. Moreover, total herbaceous standing crop was the same in control and treatment plots prior to treatment (Moore et al. 2006). Therefore, we believe that all plots possessed the same environmental potential at the beginning of the experiment. Detailed accounts of the experimental design, thinning and prescribed burn characteristics, treatment protocol, and effects on other ecosystem components are available in Covington et al. (1997) and subsequent articles (Feeney et al. 1998; Kolb et al. 1998; Kaye and Hart 1998; Mast et al. 1999; Skov et al. 2004; Boyle et al. 2005; Moore et al. 2006). Here, we briefly summarize the key aspects relevant to this study.

In 1992, a $2.4 \mathrm{~m}$ tall electrified fence was constructed to exclude ungulates from the experiment to control for grazing effects. Fuhlendorf and Engle (2004) demonstrated that grazing and fire interact in grassland systems, but, since our system did not evolve in an environment of intense grazing (Milchunas 2006), we focused on the possible interactions between fire and overstory thinning. We acknowledge that epizoochory (seed dispersal via animals) 
may be hampered due to this design. The thinning and composite treatments were thinned from below (i.e., small trees from lower crown classes were removed; Smith et al. 1997) in the fall of 1993, retaining all presettlement trees (defined as trees established prior to 1876 and/or trees $>37.5 \mathrm{~cm}$ diameter at breast height (dbh); Fulé et al. 1997) and three postsettlement trees to replace each dead presettlement tree or stump (Fulé et al. 1997; Mast et al. 1999). Thinning resulted in the removal of $\sim 2,200$ trees $^{-1}$ per hectare of the $>3,000$ trees per hectare that were present before the study began in 1992 (Covington et al. 1997), including most of the postsettlement trees. All slash was removed by hand, while all extant presettlement coarse woody debris were retained (Covington et al. 1997).

In the composite treatment, the forest floor was manipulated by raking the litter layer aside, removing accumulated forest floor duff, and returning the current ( $\sim 3$ years) litter layer to the site. To simulate the presettlement condition of a grass-dominated understory, which carried frequent fire, approximately $670 \mathrm{~kg} \mathrm{ha}^{-1}$ of herbaceous vegetation from Hart Prairie ( $4.8 \mathrm{~km}$ to the north) was harvested in late September 1994, and scattered across the plots (Covington et al. 1997); this supplementation occurred only once. The composite treatment received an initial prescribed burn in 1994, and additional prescribed burns in 1998 and 2002. All burns were conducted in October, after data collection was completed for that year.

The area within each treatment plot was stratified into four patch types: 'presettlement,' 'postsettlement removed,' 'postsettlement retained,' and 'remnant grass' (Laughlin et al. 2006). Presettlement patches consisted of groups of two or more large presettlement trees (mostly $>30 \mathrm{~cm}$ at $\mathrm{dbh}$ ). Postsettlement retained patches consisted of groups of small-diameter $(<30 \mathrm{~cm} \mathrm{dbh})$ postsettlement trees, thereby representing dense forest habitat. Postsettlement removed patches consisted of areas where all postsettlement trees were thinned and removed from the site, thereby creating openings in the canopy. Remnant grass patches were small open areas consisting of native grasses and forbs. Since the remnant grass patches represent diverse and productive stands of native herbaceous vegetation (Laughlin et al. 2006), they served as the reference community against which changes in other patch types were assessed.
A $2.5 \mathrm{~m}$ radius circular subplot was established within each patch type in each treatment plot. In total, 55 subplots were established (four per treatment plot in the thinning treatment $(n=20)$ and composite treatment $(n=20)$, and three per treatment plot in the control ( $n=15$, because controls did not contain postsettlement removed patches)). Subplots represent the range of conditions (i.e., open to full canopy) sampled within treatment plots. For this study, vegetation data were examined at the treatment-level ( $n=15$ plots) and at the patch-level within treated areas ( $n=40$ subplots).

Complete species lists were collected in two $1 \mathrm{~m}^{2}$ $(0.5 \times 2 \mathrm{~m})$ quadrats per circular subplot. For each subplot, therefore, species were noted as being present on 0,1 , or 2 quadrats. Quadrats were arranged in a wagon-wheel configuration around the circular subplot center, and were rotated each year to avoid harvesting vegetation repeatedly from the same area for another study (Moore et al. 2006). Data were collected in September for the following years: 1992 (pretreatment), 1994 (after thinning, but before the first burn), 1995, 1996, 1998, 1999, 2002, 2004, and 2005.

\section{Statistical analyses}

Separate analyses were conducted for treatment- and patch-level effects. Treatment-level effects were analyzed with plots nested within treatments as the error term. Patch-level effects were analyzed with a model that included treatment, plot nested within treatment, patch, and treatment $\times$ patch terms; the residuals formed the error term for tests of patch and treatment $\times$ patch effects. For each type of analysis, data from 1992 were analyzed to identify pretreatment differences, and data from 1994-2005 were analyzed using a repeated measures analysis to identify overall differences after treatment. Significant posttreatment differences were followed by analyses of individual years to identify particular years when effects differed. All tests were conducted with $\alpha=0.05$.

The analyses included four components: species richness (total and native), community composition, net change in composition from 1992 to 2005, and Indicator Species Analysis. Total species richness per subplot was calculated as the total number of species 
in the $2 \mathrm{~m}^{2}$ quadrats. Native species richness was calculated as the number of species native to North America, as defined by USDA NRCS (2006), per $2 \mathrm{~m}^{2}$ quadrats. Analyses of treatment and patch effects on species richness were conducted using repeated measures MANOVA with SAS JMP-IN software (version 5.1.2; SAS 2004).

We analyzed compositional differences with a distance-based permutational multivariate analysis of variance (DISTLM; Anderson 2001; McArdle and Anderson 2001). This technique is a straightforward extension of MANOVA that is applicable to multivariate response data; the test statistic is a pseudo- $F$ statistic. We used Bray-Curtis dissimilarity as our distance measure (Faith et al. 1987), and 9,999 permutations to calculate the significance of the pseudo- $F$ statistic. The net change in composition from 1992 to 2005 was assessed by calculating the Bray-Curtis distance measure for each subplot based on its composition in these years. This distance ranges from 0 (completely identical) to 1 (completely dissimilar). As recommended by McCune and Grace (2002), analyses of community composition were restricted to species that occurred on at least $5 \%$ of subplots (out of all 495 subplot-year combinations).

Indicator Species Analysis (ISA; Dufrêne and Legendre 1997) was used to identify species associated with the observed differences among treatments and patches. Since we were trying to explain these differences, we only conducted ISAs for years, in which composition differed among treatments (19982005; see Results, below). Further, since the results of an ISA depend on how data are grouped (Dufrêne and Legendre 1997), we used the results of the compositional analysis (see Results, below) to identify the comparisons of interest. Two biologically motivated comparisons were made among treatments: (1) control versus treated (a combination of composite and thinning treatments) to examine species responses to thinning, and (2) composite versus unburned (a combination of control and thinning treatments) to examine species responses to burning. Patch effects were compared between presettlement, postsettlement (a combination of retained and removed), and remnant grass patches. If a species was an indicator in both comparisons for treatment effect, it was identified as an indicator of the group in which its Indicator Value (IV) was greatest. However, a given species could be an indicator of treatment and of patch effects, as these effects are not hierarchical. An IV was calculated independently for each species as the product of its relative abundance and frequency, and the significance of the calculated IV was assessed using 999 Monte Carlo randomizations. ISAs were conducted using code written for R (v. 2.2.1; code available from J.D. Bakker). A separate ISA was conducted for each year, and results were combined using meta-analytical techniques (Bakker 2005). For a given species in a given group, the IVs from every year, that it occurred, were averaged to yield a mean IV, and the associated $P$-values were combined using a weighted Z-transform (Whitlock 2005). Combining results from multiple years reduces the likelihood of spurious results (Bakker 2005). We required that significant indicators have a mean IV $\geq 25$ and combined $P$ value $<0.05$ (Dufrêne and Legendre 1997).

\section{Results}

Eighty-nine species were detected in the study area from 1992 to 2005 . Thirty-nine species occurred on at least $5 \%$ of the subplot-year combinations, and were included in analyses of community composition.

\section{Treatment effects}

Total species richness (per $2 \mathrm{~m}^{2}$ ) was similar among treatments in 1992 before treatment $\left(F_{2,12}=1.00\right.$, $P=0.394$ ), but not after treatment (repeated measures analysis of 1994-2005 data: $F_{2,12}=5.19$, $P=0.024)$. Richness remained similar among treatments until 11 and 12 years after treatment (2004, 2005), when more species occurred in the composite than in control or thinning treatments (Fig. 1). Similar results were obtained when native species richness was analyzed separately (data not shown).

Species richness was temporally variable (Fig. 1). Mean species richness within plots was not correlated with interannual precipitation $(P>0.05)$. However, the severe drought of 2002 coincided with a noticeable reduction in species richness across all treatments (Fig. 1).

Plant community composition was similar among treatments in 1992 before treatment, but not after treatment (Table 1). Composition first diverged among treatments in 1998, 5 years after the overstory 


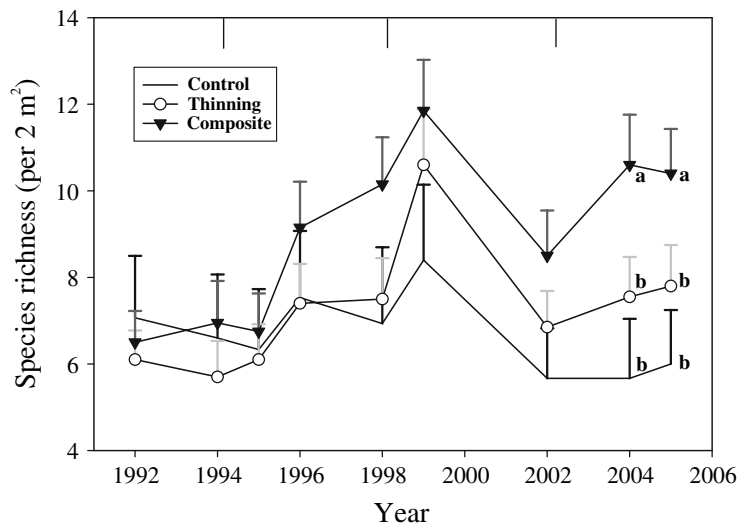

Fig. 1 Total species richness ( +1 standard error) at the $2 \mathrm{~m}^{2}$ subplot scale $(n=55)$ remained similar among treatments until 11 and 12 years after treatment $(2004,2005)$. Within each year, treatments that differ from one another are indicated with different lowercase letters; letters are not shown if treatments did not differ. Analyses of native species richness yielded similar results. Overstory thinning occurred in 1993, and prescribed fires (denoted by vertical lines at top) occurred after sampling in 1994, 1998, and 2002

was thinned, but were not consistent through time. In 1998, 1999, 2004, and 2005, composition differed between the composite and control treatments, but composition in the composite treatment was similar to the control during the severe drought of 2002. In 1999 and 2002, composition differed among the thinning and control treatments, while composition differed among the thinning and composite treatments in 2002 and 2004.

The net change in composition from 1992 to 2005 was significantly greater $\left(F_{2,12}=3.89, P=0.047\right)$ for the composite treatment (mean Bray-Curtis distance $=0.59$ ) than the control treatment (mean Bray-Curtis distance $=0.36$ ). The thinning treatment had a mean Bray-Curtis distance of 0.44, which did not differ from either the composite treatment or the control.

No species were indicators of the control treatment (Table 2). Two $\mathrm{C}_{3}$ grasses (Elymus elymoides, Festuca arizonica) and two legumes (Astragalus rusbyi, Vicia spp.) were indicators of treated plots (combination of composite and thinned treatments). Lupinus argenteus, a legume, and Verbascum thapsus, a nonnative forb, were indicators of the burned composite treatment. One $\mathrm{C}_{4}$ grass, Muhlenbergia montana, was an indicator of unburned plots (combination of control and thinning treatments).

Patch effects

Before treatment, total species richness (per $2 \mathrm{~m}^{2}$ ) was greatest in remnant grass patches and lowest in presettlement patches $\left(F_{3,24}=121.50, P<0.001\right.$; Fig. 2). Following treatment, richness continued to differ among patch types (repeated measures analysis of 1994-2005 data: $F_{3,24}=33.70, P<0.001$ ) but the treatment $\times$ patch interaction was not significant $\left(F_{3,24}=0.36, P=0.785\right)$, indicating that patch types in the composite and thinning treatments responded similarly. Presettlement patches always had the lowest richness, and remnant grass patches generally had the highest richness, though richness increased in
Table 1 Restoration treatments did not affect community composition until 5 years after initial treatment

\begin{tabular}{llllll}
\hline Year & Pseudo- $F_{2,12}$ & $P$ & & \multicolumn{2}{l}{ Differences among treatments } \\
\cline { 4 - 5 } & & & Control & Thinning & Composite \\
\hline Pre-treatment & & & & & \\
1992 & 0.72 & 0.720 & & & \\
Posttreatment & & & & & \\
$1994-2005^{*}$ & 1.73 & 0.049 & & $\mathrm{~b}$ & \\
1994 & 1.09 & 0.396 & & $\mathrm{~b}$ & \\
1995 & 1.44 & 0.141 & & $\mathrm{~b}$ & $\mathrm{a}$ \\
1996 & 1.42 & 0.147 & & $\mathrm{~b}$ & $\mathrm{~b}$ \\
1998 & 1.83 & 0.025 & $\mathrm{a}$ & $\mathrm{b}$ & \\
1999 & 2.34 & 0.009 & $\mathrm{a}$ & $\mathrm{b}$ & \\
2002 & 1.84 & 0.008 & $\mathrm{a}$ & $\mathrm{b}$ & \\
2004 & 2.46 & 0.001 & $\mathrm{a}$ & $\mathrm{b}$ & \\
2005 & 1.90 & 0.026 & $\mathrm{a}$ & & \\
\hline
\end{tabular}


Table 2 Indicator species associated with treatments from 1998 to 2005

\begin{tabular}{|c|c|c|c|c|c|c|}
\hline Treatment & Species & Mean IV & Combined $P$ & Life form & Postfire regeneration strategy ${ }^{c}$ & Nativity \\
\hline \multicolumn{7}{|c|}{ Comparison 1: control versus treated } \\
\hline Control & No indicator species & - & - & & & \\
\hline \multirow[t]{4}{*}{ Treated $^{\mathrm{a}}$} & Astragalus rusbyi & 25.0 & $<0.001$ & Herbaceous legume & Sprouter & Native $^{\mathrm{d}}$ \\
\hline & Elymus elymoides & 54.1 & $<0.001$ & $\mathrm{C}_{3}$ grass & Sprouter, seeder & Native \\
\hline & Festuca arizonica & 31.3 & 0.041 & $\mathrm{C}_{3}$ bunchgrass & Sprouter & Native \\
\hline & Vicia spp. & 26.7 & 0.001 & Herbaceous legume & Sprouter & Native \\
\hline \multicolumn{7}{|c|}{ Comparison 2: composite (burned) versus unburned } \\
\hline \multirow[t]{2}{*}{ Composite } & Lupinus argenteus & 30.3 & $<0.001$ & Herbaceous legume & Sprouter, seeder & Native \\
\hline & Verbascum thapsus & 25.2 & $<0.001$ & Biennial forb & Seeder & Nonnative \\
\hline Unburned $^{\mathrm{b}}$ & Muhlenbergia montana & 34.0 & 0.007 & $\mathrm{C}_{4}$ bunchgrass & Sprouter & Native \\
\hline
\end{tabular}

A separate Indicator Species Analysis was conducted for each year using all subplots $(n=55)$, and results were combined using meta-analytic techniques

${ }^{\text {a }}$ Combination of composite and thinning treatments

b Combination of control and thinning treatments

c Species are classified as either a sprouter, a seeder, or both (Whelan 1995), based on published and unpublished sources of information summarized in the U.S. Department of Agriculture Forest Service's Fire Effects Information System (http:// www.fs.fed.us/database/feis/)

d Astragalus rusbyi has been listed as a sensitive species on the Coconino National Forest due to its limited range

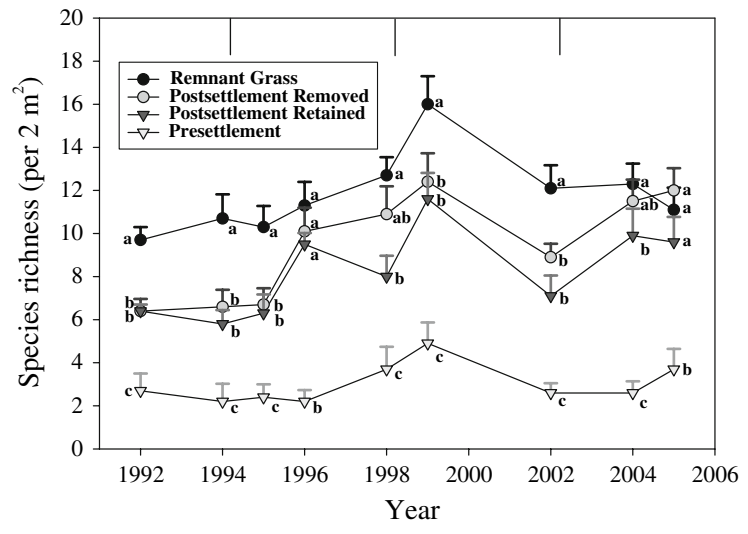

Fig. 2 Total species richness ( +1 standard error) at the $2 \mathrm{~m}^{2}$ subplot scale $(n=40)$ differed among patch types within treated areas at the beginning of the study, but richness in postsettlement removed and postsettlement retained patches increased to similar levels detected in the remnant grass patches over time. Within each year, different letters indicate differences among patch types. Analyses of native species richness yielded similar results. Overstory thinning occurred in 1993, and prescribed fires (denoted by vertical lines at top) occurred after sampling in 1994, 1998, and 2002

both types of postsettlement patches. In particular, richness was similar between remnant grass and postsettlement removed patches in 1996, 1998, 2004, and 2005, and between remnant grass and postsettlement retained patches in 1996 and 2005. Similar results were obtained when we analyzed native species richness exclusively (data not shown).

Community composition differed among patch types prior to treatment. Remnant grass and presettlement patches were distinct from one another and from both types of postsettlement patches (Table 3). These inter-patch differences persisted after treatment, and did not differ among thinning and composite treatments. Interannual differences were minimal, though the composition of the postsettlement removed and postsettlement retained patches diverged in 2002 and 2005.

The net change in composition from 1992 to 2005 differed among patch types $\left(F_{3,24}=5.96, P=0.004\right)$. The magnitude of change was greatest for presettlement patches (mean Bray-Curtis distance $=0.73$ ) and lowest for remnant grass patches (mean Bray-Curtis distance $=0.32$ ). Postsettlement removed and postsettlement retained patches had intermediate mean Bray-Curtis distances (removed: 0.56; retained: 0.44), and did not differ from other patch types. The treatment $\times$ patch interaction was not significant $\left(F_{3,24}=0.36, P=0.780\right)$. 
Table 3 Community composition remained distinct among patch types throughout the experiment

Within each year, treatments that differed from one another are indicated with different lowercase letters. The treatment $\times$ patch interaction was not significant (repeated measures analysis of 19942005 data: pseudo$F_{3,24}=0.63, P=0.917$ )

*Repeated measures analysis

\begin{tabular}{lllllll}
\hline Year & $\begin{array}{l}\text { Pseudo- } \\
F_{3,24}\end{array}$ & $P$ & \multicolumn{2}{l}{ Differences among patch types } & \\
\cline { 5 - 7 } & & & Presettlement & $\begin{array}{l}\text { Postsettlement } \\
\text { retained }\end{array}$ & $\begin{array}{l}\text { Postsettlement } \\
\text { removed }\end{array}$ & $\begin{array}{l}\text { Remnant } \\
\text { grass }\end{array}$ \\
\hline Pretreatment & & & & $\mathrm{b}$ & $\mathrm{c}$ \\
1992 & 5.91 & $<0.001$ & $\mathrm{a}$ & $\mathrm{b}$ & & $\mathrm{c}$ \\
Posttreatment & & & & & $\mathrm{b}$ & $\mathrm{c}$ \\
$1994-2005^{*}$ & 6.17 & $<0.001$ & $\mathrm{a}$ & $\mathrm{b}$ & $\mathrm{b}$ & $\mathrm{c}$ \\
1994 & 5.66 & $<0.001$ & $\mathrm{a}$ & $\mathrm{b}$ & $\mathrm{b}$ & $\mathrm{c}$ \\
1995 & 4.37 & $<0.001$ & $\mathrm{a}$ & $\mathrm{b}$ & $\mathrm{b}$ & $\mathrm{c}$ \\
1996 & 4.19 & $<0.001$ & $\mathrm{a}$ & $\mathrm{b}$ & $\mathrm{b}$ & $\mathrm{d}$ \\
1998 & 3.85 & $<0.001$ & $\mathrm{a}$ & $\mathrm{b}$ & $\mathrm{b}$ & $\mathrm{c}$ \\
1999 & 4.38 & $<0.001$ & $\mathrm{a}$ & $\mathrm{b}$ & $\mathrm{c}$ & $\mathrm{d}$ \\
2002 & 3.56 & $<0.001$ & $\mathrm{a}$ & $\mathrm{b}$ & $\mathrm{b}$ & $\mathrm{c}$ \\
2004 & 3.47 & $<0.001$ & $\mathrm{a}$ & $\mathrm{bc}$ & $\mathrm{b}$ & \\
2005 & 4.24 & $<0.001$ & $\mathrm{a}$ & $\mathrm{b}$ & & \\
\hline
\end{tabular}

No species were indicators of the presettlement patch type, and Elymus elymoides was the only indicator of postsettlement (combination of postsettlement retained and postsettlement removed) patch types (Table 4). Nine species were indicators of remnant grass patches, including three $\mathrm{C}_{3}$ graminoids (Carex geophila, Festuca arizonica, Poa fendleriana), one $\mathrm{C}_{4}$ graminoid (Muhlenbergia montana), three legumes (Astragalus rusbyi, Lupinus argenteus, Vicia spp.), and two non-leguminous perennial forbs (Achillea millefolium, Cirsium wheeleri).

Table 4 Indicator species associated with patch types from 1992 to 2005

A separate Indicator

Species Analysis was conducted for each year using subplots from the thinning and composite treatments $(n=40)$, and results were combined using meta-analytic techniques. All species in this table are native

a Combination of postsettlement retained and postsettlement removed patch types

\section{Discussion}

\section{Treatment effects}

Increased pine densities and cessation of a frequentfire regime are thought to have reduced species richness and altered the composition of understory plant communities in ponderosa pine forests (Covington and Moore 1994; Allen et al. 2002). This study supports these assumptions, since reducing pine densities and applying prescribed fire increased native species richness and altered community

\begin{tabular}{|c|c|c|c|c|}
\hline Patch type & Species & Mean IV & $\begin{array}{l}\text { Combined } \\
P\end{array}$ & Life form \\
\hline Presettlement & No indicator species & - & - & \\
\hline Postsettlement $^{\mathrm{a}}$ & Elymus elymoides & 40.9 & $<0.001$ & $\mathrm{C}_{3}$ grass \\
\hline \multirow[t]{9}{*}{ Remnant Grass } & Achillea millefolium & 36.0 & $<0.001$ & Perennial forb \\
\hline & Astragalus rusbyi & 26.8 & 0.013 & $\begin{array}{c}\text { Herbaceous } \\
\text { legume }\end{array}$ \\
\hline & Carex geophila & 48.0 & $<0.001$ & $\mathrm{C}_{3}$ sedge \\
\hline & Cirsium wheeleri & 29.7 & $<0.001$ & Perennial forb \\
\hline & Festuca arizonica & 66.0 & $<0.001$ & $\mathrm{C}_{3}$ bunchgrass \\
\hline & Lupinus argenteus & 64.5 & $<0.001$ & $\begin{array}{c}\text { Herbaceous } \\
\text { legume }\end{array}$ \\
\hline & $\begin{array}{c}\text { Muhlenbergia } \\
\text { montana }\end{array}$ & 63.8 & $<0.001$ & $\mathrm{C}_{4}$ bunchgrass \\
\hline & Poa fendleriana & 33.7 & $<0.001$ & $\mathrm{C}_{3}$ bunchgrass \\
\hline & Vicia spp. & 63.7 & $<0.001$ & $\begin{array}{c}\text { Herbaceous } \\
\text { legume }\end{array}$ \\
\hline
\end{tabular}


composition. However, these changes may occur slowly, and may not be detectable for many years. Thus, long-term monitoring is essential when evaluating the success of restoration treatments.

We expected to observe increases in species richness in both thinning and composite treatments. Pine trees intercept light (Naumburg and DeWald 1999) and precipitation (McLaughlin 1978), produce abundant needle-fall, and compete for soil nutrients near the soil surface. All these mechanisms can impact herbaceous productivity and species composition due to interspecific differences in response to resource availability (Riegel et al. 1995). In this experiment, thinning alone did not increase species richness, whereas thinning plus repeated burning increased species richness 11 years after initial treatment (Fig. 1). Repeated disturbances, such as prescribed fire, likely reduced competitive interactions among dominant species (Huston 1979), and created sites for seedling establishment (Grime 1977), thereby promoting species coexistence at small spatial scales.

While restoration treatments did not result in increased richness until more than a decade after initial treatment, herbaceous standing crop increased rapidly (Moore et al. 2006). Species richness exhibits a quadratic relationship with total standing crop within a given year (D.C. Laughlin and M.M. Moore, unpublished data), such that species richness is maximal at approximately $100 \mathrm{~g} \mathrm{~m}^{-2}$. The 'humpshaped' relationship between richness and standing crop suggests that richness is regulated at the higher levels of herbaceous production due to competitive exclusion and recruitment limitation (Grime 1979; Keddy 2005). This suggests that management goals of increasing productivity and diversity at relatively small scales cannot be achieved simultaneously if herbaceous productivity levels are too high.

We did not directly study colonizing mechanisms that might have led to increased species richness. However, 15 species that were present in 2004 and 2005 were not present at the beginning of the study, suggesting that they colonized from the soil seed bank or from off-site population sources. Observed increases in species richness were not entirely due to new colonists, but were likely also caused by dispersal from adjacent remnant grass patches. Approximately half of these new colonists were annuals, which is consistent with research suggesting that reintroducing fire into these systems increases the richness and abundance of native annuals (Laughlin et al. 2004, 2005, 2006; Fulé et al. 2005; Moore et al. 2006). The exclusion of ungulates from the study area may have hampered dispersal of off-site species dependent on epizoochory.

Long-term experiments allow for comparisons of treatments among climatically variable years (Tilman 1989). The severe drought of 2002 (77\% below normal precipitation) coincided with reduced species richness among all treatments. Water is a major limiting resource in semi-arid systems (e.g., Breshears et al. 2005), and the lack of water in 2002 likely contributed to the temporary loss of species in the community. However, richness began to increase again after the severe drought. Interestingly, the severe drought apparently nullified the compositional differences between the composite and control treatments, yet the thinning treatment remained distinct. This further demonstrates the need for long-term evaluations of treatment effects in order to understand the background variation caused by interannual climatic variability.

The treatments significantly altered community composition after 5 years. Two native cool-season grasses, Festuca arizonica and Elymus elymoides, were indicators of treated rather than control areas, suggesting that thinning the overstory canopy promoted their establishment (Naumburg and DeWald 1999; Naumburg et al. 2001). However, a dominant warm-season native bunchgrass, Muhlenbergia montana, was negatively affected by repeated prescribed fires that occurred in the fall, which is consistent with published reports for $M$. montana (Gaines et al. 1958), but counter to the recent hypothesis that increased fire frequency is linked to the expansion of $\mathrm{C}_{4}$ graminoids (Keeley and Rundel 2005). This effect may relate to the season of burn; $M$. montana would likely be favored by burns that occur before it starts investing energy in vegetative growth. Vose and White (1991) concluded that the net effect of a prescribed fire on M. montana was negative due to high mortality and low seedling recruitment. Fireinduced mortality might be directly due to the buildup of dry flammable material at the base of $M$. montana plants (Vose and White 1991). Two native leguminous forbs, Vicia spp. and the endemic Astragalus rusbyi, were also more frequent and abundant in both treatments. These species can 
increase the rate of nitrogen fixation, a critical ecosystem function in this nitrogen-limited ecosystem. Notably, A. rusbyi has been listed as a sensitive species by the U.S. Forest Service due to its limited range, and its positive response to restoration treatments is encouraging.

Compositional changes may not be desirable if they involve increases in nonnative species. Relatively few nonnative species were present in our study area, however, likely because the site has been little disturbed for nearly a century (Korb et al. 2005). Verbascum thapsus, a nonnative biennial, was an indicator of the composite treatment, consistent with the findings of Korb et al. (2005). Disturbanceadapted nonnative species can increase after wildfires (Crawford et al. 2001; Griffis et al. 2001), and prescribed fires (Wolfson 2005) in southwestern ponderosa pine forests and in other regions (Dodson and Fiedler 2006; Keeley 2006). No nonnative species were indicators of the thinning treatment. Therefore, scheduling longer burn intervals (see also Keeley (2006) and Fulé and Laughlin (2007)), or refraining from burning in thinned forests, especially where fuel loads are not considered hazardous, may reduce nonnative species establishment. However, this option must be weighed against the potential loss of frequent fire-dependent species.

These results illustrate the importance of longterm monitoring, but care should be taken when extrapolating beyond the scale of this study. The treatments implemented in 1993 are not operationally feasible at landscape scales due to logistical constraints, though traditional thinning and burning techniques are occurring at landscape scales. Furthermore, this experiment was conducted at a site with uniform soils, and response variables were analyzed at a single spatial scale. More research is needed to assess the generality of these results on other soil types and at other spatial scales.

\section{Patch effects}

Response to restoration treatments differed among forest patch types. The remnant grass patches are viewed as being the most similar to pre-Euroamerican settlement reference conditions (Laughlin et al. 2006), and therefore, served as the target against which changes in other patch types were compared.
Species richness in postsettlement removed and postsettlement retained patches increased to levels found in remnant grass patches toward the end of the study (Fig. 2). Species richness did not increase in presettlement tree patches where large trees suppress understory vegetation. These results highlight the importance of creating sufficiently large gaps in the canopy within treatments because a few retained trees can have a disproportionately large effect on understory responses (Moore and Deiter 1992).

Postsettlement removed and postsettlement retained patches were disturbed by harvesting activities and by prescribed fires in the composite treatment. Composition of these patches remained distinct from that of the remnant grass patches (Table 3), suggesting that removing some or all of the small diameter trees, and applying prescribed fire, were not enough to restore community composition in this time frame. Elymus elymoides, the only indicator of postsettlement patches, colonizes disturbed sites rapidly (Jones 1998), likely due to its highly mobile wind-dispersed caryopses, and high germination rates. E. elymoides may be an important facilitator of postfire vegetation dynamics.

While most indicators of remnant grass patches (Table 4) were already abundant in these patches in 1992 and maintained their abundance through 2005, two species (Astragalus rusbyi and Poa fendleriana) increased in frequency and abundance from 1992 to 2005. However, no indicators of remnant grass patches have become very abundant in the postsettlement removed and postsettlement retained patches. Further research is needed to determine whether these species are dispersal or microsite limited, and the degree to which competition with neighboring vegetation affects their spread. Diversity and composition of postsettlement removed and retained patches might be enhanced by outplanting nurserygrown plugs or by seeding native species (Springer and Laughlin 2004), though seeding in semi-arid forests is often not very successful.

\section{Conclusion}

Restoring the composition of a plant community is a difficult task compared to restoring ecological structure or function (Lockwood and Pimm 1999). The results from this study suggest that restoration 
treatments can significantly increase species richness, and alter understory plant community composition in a pine-bunchgrass ecosystem. However, these changes may not be detectable for many years, and can vary temporally in response to events such as severe droughts. Thus, the value of long-term studies increases with each year of monitoring. Though diversity increased in patches where small trees were removed, composition continued to differ among remnant grass patches and other patch types, suggesting that composition changes slowly in this system. While nonnative species were minimal in the study area, one such species was abundant where prescribed fires occurred. Scheduling longer intervals between prescribed burns or refraining from burning in thinned forests, especially where fuel loads are not hazardous, may reduce invasion by nonnative species, but may hinder goals of increasing diversity. In the ponderosa pine-bunchgrass ecosystems of the southwestern United States, land managers may expect rapid responses in herbaceous understory production following treatment, but should not expect rapid responses in diversity and composition.

Acknowledgments We thank the staff and students of the Ecological Restoration Institute at Northern Arizona University (NAU). Particular thanks go to W. W. Covington, P. Z. Fulé, J. P. Roccaforte, J. Barber, L. Labate, M. Stoddard, L. Machina, and S. Curran. Thanks to the USDA Forest Service Coconino National Forest, especially for assistance with prescribed burns, and the Rocky Mountain Research Station, especially C. Edminster, for helping establish the experiment. Funding was provided by a National Science Foundation grant (DEB9322706), McIntire-Stennis appropriations to the NAU School of Forestry, and the Ecological Restoration Institute. Funding for remeasurement and analysis in 2004 was provided by the USDA Forest Service, \#03-DG-11031600-088.

\section{References}

Allen CD, Savage M, Falk DA, Suckling KF, Swetnam TW, Schulke T, Stacey PB, Morgan P, Hoffman M, Klingel JT (2002) Ecological restoration of southwestern ponderosa pine ecosystems: a broad perspective. Ecol Appl 12:1418-1433

Anderson MJ (2001) A new method for non-parametric multivariate analysis of variance. Austral Ecol 26:32-46

Avery CC, Larson FR, Schubert GH (1976) Fifty-year records of virgin stand development in southwestern ponderosa pine. USDA Forest Service General Technical Report RM-22. $71 \mathrm{p}$

Bakker JD (2005) Long-term vegetation dynamics of ponderosa pine forests $\mathrm{PhD}$ Dissertation. Northern Arizona University, Flagstaff
Bakker JD, Moore MM (2007) Controls on vegetation structure in southwestern ponderosa pine forests, 1941 and 2004. Ecology 88:2305-2319

Boyle SI, Hart SC, Kaye JP, Waldrop MP (2005) Restoration and canopy type influence soil microflora in a ponderosa pine forest. Soil Sci Soc Am J 69:1627-1638

Breshears DD, Cobb NS, Rich PM, Price KP, Allen CD, Balice RG, Romme WH, Kastens JH, Floyd ML, Belnap J, Anderson JJ, Myers OB, Meyer CW (2005) Regional vegetation die-off in response to global-change-type drought. Proc Natl Acad Sci 102:15144-15148

Christian JM, Wilson SD (1999) Long-term ecosystem impacts of an introduced grass in the northern Great Plains. Ecology 80:2397-2407

Cortina J, Maestre FT, Vallejo R, Baeza MJ, Valdecantos A, Pérez-Devesa M (2006) Ecosystem structure, function, and restoration success: are they related? J Nat Conserv 14:152-160

Covington WW, Moore MM (1994) Southwestern ponderosa pine forest structure: changes since Euro-American settlement. J For 92:39-47

Covington WW, Fulé PZ, Moore MM, Hart SC, Kolb TE, Mast JN, Sackett SS, Wagner MR (1997) Restoring ecosystem health in ponderosa pine forests of the Southwest. J For 95:23-29

Crawford JA, Wahren C-HA, Kyle S, Moir WH (2001) Responses of exotic plant species to fires in Pinus ponderosa forests in northern Arizona. J Veg Sci 12:261-268

Dietrich JH (1980) Chimney Spring forest fire history. USDA Forest Service Research Paper RM-220

Dodson EK, Fiedler CE (2006) Impacts of restoration treatments on alien plant invasion in Pinus ponderosa forests, Montana, USA. J Appl Ecol 43:887-897

Dufrêne M, Legendre P (1997) Species assemblages and indicator species: the need for a flexible asymmetrical approach. Ecol Monogr 67:345-366

Faith DP, Minchin PR, Belbin L (1987) Compositional dissimilarity as a robust measure of ecological distance. Vegetation 69:57-68

Feeney SR, Kolb TE, Wagner MR, Covington WW (1998) Influence of thinning and burning restoration treatments on presettlement ponderosa pines at the Gus Pearson Natural Area. Can J For Res 28:1295-1306

Fuhlendorf SD, Engle DM (2004) Application of the firegrazing interaction to restore a shifting mosaic on tallgrass prairie. J Appl Ecol 41:604-614

Fulé PZ, Covington WW, Moore MM (1997) Determining reference conditions for ecosystem management of southwestern ponderosa pine forests. Ecol Appl 7:895-908

Fulé PZ, Laughlin DC, Covington WW (2005) Pine-oak forest dynamics five years after ecological restoration treatments, Arizona, USA. For Ecol Manage 218:129-145

Fulé PZ, Laughlin DC (2007) Wildland fire effects on forest structure over an altitudinal gradient, Grand Canyon National Park, USA. J Appl Ecol 44:136-146

Gaines EM, Kallander HR, Wagner JE (1958) Controlled burning in southwestern ponderosa pine: results from the Blue Mountain plots, Fort Apache Indian Reservation. J For 56:323-327

Griffis KL, Crawford JA, Wagner MR, Moir WH (2001) Understory response to management treatments in 
northern Arizona ponderosa pine forests. For Ecol Manage 146:239-245

Grime JP (1977) Evidence for the existence of three primary strategies in plants and its relevance to ecological and evolutionary theory. Am Nat 111:1169-1195

Grime JP (1979) Plant strategies and vegetation processes. John Wiley \& Sons, New York

Huston M (1979) A general hypothesis of species diversity. Am Nat 113:81-101

Jones TA (1998) Viewpoint: the present status and future prospects of squirreltail research. J Range Manage 51:326-331

Kaye JP, Hart SC (1998) Ecological restoration alters nitrogen transformations in a ponderosa pine-bunchgrass ecosystem. Ecol Appl 8:1052-1060

Keddy P (2005) Putting the plants back into plant ecology: six pragmatic models for understanding diversity and conserving plant diversity. Ann Bot 96:177-189

Keddy PA, Smith L, Campbell DR, Clark M, Montz G (2006) Patterns of herbaceous plant diversity in southeastern Louisiana pine savannas. Appl Veg Sci 9:17-26

Keeley JE, Rundel PH (2005) Fire and the Miocene expansion of C4 grasslands. Ecol Lett 8:683-690

Keeley JE (2006) Fire management impacts on invasive plants in the western United States. Conserv Biol 20:375-384

Kerns BK, Moore MM, Timpson ME, Hart SC (2003) Soil properties associated with vegetation patches in a Pinus ponderosa-bunchgrass mosaic. West N Am Nat 63:452-462

Kolb TE, Holmberg KM, Wagner MR, Stone JE (1998) Regulation of ponderosa pine foliar physiology and insect resistance mechanisms by basal area treatment. Tree Physiol 18:375-381

Korb JE, Springer JD, Powers SR, Moore MM (2005) Soil seed banks in Pinus ponderosa forests in Arizona: clues to site history and restoration potential. Appl Veg Sci 8:103-112

Laughlin DC, Bakker JD, Stoddard MT, Daniels ML, Springer JD, Gildar CN, Green AM, Covington WW (2004) Toward reference conditions: wildfire effects on flora in an old-growth ponderosa pine forest. For Ecol Manage 199:137-152

Laughlin DC, Bakker JD, Fule PZ (2005) Understorey plant community structure in lower montane and subalpine forests, Grand Canyon National Park, USA. J Biogeogr 32:2083-2102

Laughlin DC, Moore MM, Bakker JD, Casey CA, Springer JD, Fulé PZ, Covington WW (2006) Assessing targets for restoration of herbaceous vegetation in ponderosa pine forests. Restor Ecol 14:548-560

Legendre P, Legendre L (1998) Numerical ecology, 2nd edn. Developments in environmental modelling 20. Elsevier Science B.V., Amsterdam, The Netherlands. $853 \mathrm{p}$

Lindborg R, Eriksson O (2004) Effects of restoration on plant species richness and composition in scandinavian seminatural grasslands. Restor Ecol 12:318-326

Lockwood JL, Pimm SL (1999) When does restoration succeed? In: Weiher E, Keddy P (eds) Ecological assembly rules: perspectives, advances, retreats. Cambridge University Press, Cambridge

MacDougall AS, Turkington R (2005) Are invasive species the drivers or passengers of change in degraded ecosystems? Ecology 86:42-55
Mast JN, Fulé PZ, Moore MM, Covington WW, Waltz AEM (1999) Restoration of presettlement age structure of an Arizona ponderosa pine forest. Ecol Appl 9:228-239

McArdle BH, Anderson MJ (2001) Fitting multivariate models to community data: a comment on distance-based redundancy analysis. Ecology 82:290-297

McCune B, Grace JB (2002) Analysis of ecological communities. MjM Software Design, Gleneden Beach, OR. 300 p

McLaughlin SP (1978) Overstory attributes, light, throughfall, and the interpretation of overstory-understory relationships. For Sci 24:550-553

Milchunas DG (2006) Responses of plant communities to grazing in the southwestern United States. USDA Forest Service, Rocky Mountain Research Station, Fort Collins, CO, USA, RMRS-GTR-169

Moore MM, Deiter DA (1992) Stand density index as a predictor of forage production in northern Arizona pine forests. J Range Manage 45:267-271

Moore MM, Casey CA, Bakker JD, Springer JD, Fulé PZ, Covington WW, Laughlin DC (2006) Herbaceous vegetation responses (1992-2004) to restoration treatments in a ponderosa pine forest. Rangeland Ecol Manage 59:135-144

National Oceanic and Atmospheric Administration [NOAA] (2005) Accessed 25 January, 2005 (http://www.noaa.gov)

Naumburg E, DeWald LE (1999) Relationships between Pinus ponderosa forest structure, light characteristics, and understory graminoid species presence and abundance. For Ecol Manage 124:205-215

Naumburg E, DeWald LE, Kolb TE (2001) Shade responses of five grasses native to southwestern Pinus ponderosa forests. Can J Bot 79:1001-1009

Olberding SD (2000) Fort Valley: the beginnings of forest research. Forest History Today, Spring, 9-15

Riegel GM, Miller RF, Krueger WC (1995) The effects of aboveground and belowground competition on understory species composition in a Pinus ponderosa forest. For Sci 41:864-889

SAS Institute, Inc. (2004) JMP-IN ver 5.1.2. Statistical analysis software. SAS Institute, Inc., Cary, NC

Schwartz MW, Brigham CA, Hoeksma JD, Lyons KG, Mills MH, van Mantgem PJ (2000) Linking biodiversity to ecosystem function: implications for conservation ecology. Oecologia 122:297-305

Skov KR, Kolb TE, Wallin KF (2004) Tree size and drought affect ponderosa pine physiological response to thinning and burning treatments. For Sci 50:81-91

Smith DM, Larson BC, Kelty MJ, Ashto PMS (1997) The practice of silviculture: applied forest ecology. John Wiley \& Sons, Inc., New York

Springer JD, Laughlin DC (2004) Seeding with natives increases species richness in a dry ponderosa pine forest (Arizona). Ecol Restor 22:220-221

Tilman D (1982) Resource competition and community structure. Monographs in Population Biology. Princeton University Press, Princeton

Tilman D (1989) Ecological experimentation: strengths and conceptual problems. In: Likens GE (eds), Long-term studies in ecology: approaches and alternatives. SpringerVerlag, New York

Tilman D, Knops J, Wedin D, Reich P (2002) Plant diversity and composition: effects on productivity and nutrient 
dynamics of experimental grasslands. In: Loreau M, Naeem S, Inchausti I (eds) Biodiversity and ecosystem functioning: synthesis and perspectives. Oxford University Press, Oxford, UK

USDA, NRCS [United States Department of Agriculture, Natural Resources Conservation Service] (2006) The PLANTS Database (http://plants.usda.gov, 5 September 2006). National Plant Data Center, Baton Rouge, LA 70874-4490 USA

Vose JM, White AS (1991) Biomass response mechanisms of understory species the first year after prescribed burning in an Arizona ponderosa-pine community. For Ecol Manage 40:175-187

Whelan RJ (1995) The ecology of fire. Cambridge University Press, Cambridge

Whitlock MC (2005) Combining probability from independent tests: the weighted Z-method is superior to Fisher's approach. J Evol Biol 18:1368-1373

Wolfson BAS, Kolb TE, Sieg CH, Clancy KM (2005) Effects of post-fire conditions on germination and seedling success of diffuse knapweed in northern Arizona. For Ecol Manage 216:342-358 